\title{
HUMAN BODY AND TECHNIQUE, THE IDEA OF PROGRESS, AND USAIN BOLT'S 100M DASH IN BEIJING 2008: AN INTERDISCIPLINARY ANALYSIS OF A PARADIGM CHANGING PERFORMANCE
}

\begin{abstract}
CUERPO HUMANO Y TÉCNICA, LA IDEA DE PROGRESO Y LOS 100M LLANOS DE USAIN BOLT EN BEIJING 2008: UN ANÁLISIS INTERDISCIPLINARIO DE UNA ACTUACIÓN QUE CAMBIÓ EL PARADIGMA ACEPTADO
\end{abstract}

\author{
TÉCNICA E CORPO HUMANO, A IDEIA DO PROGRESSO, E O TRABALHO DE 100M DE BOLT EM BEIJING \\ 2008: UMA ANÁLISE INTERDISCIPLINAR DE UM PARADIGMA MUDANDO O DESEMPENHO
}

\section{Mariano Gonzalez Leoni ${ }^{1}$}

\begin{abstract}
Through history, numerous events have taught us that the beliefs we once thought to be certainties were in fact mistaken, due to a lack of information. Still, in many occasions we tend to fall into the same cycle, believing that this time around we are actually on the right side of things, and that our newly acquired knowledge is a part of the progression to the betterment of humanity. The present research simply intends to present an example from the popular world of sports that shows how little we actually know about some of the closest things to us, such as our own bodies or the technique required to run straight, and how one single case is enough to disregard decades of assumed scientific certainty. This interdisciplinary approach to Usain Bolt's case only attempts to shed some light over our ignorance, and specially in our pretentious assumptions regarding human knowledge. This humble approach is absolutely necessary in our quest to improve education in our society.
\end{abstract}

Keywords: Sports. Change. Knowledge.

Resumen: A lo largo de la historia, numerosos eventos nos han enseñado que creencias que creíamos que eran certezas estaban en realidad equivocadas, debido a una falta de información. De todas maneras, en muchas ocasiones tendemos a caer en el mismo ciclo, creyendo que esta vez si estamos en lo correcto, y que nuestro nuevo conocimiento es parte de un movimiento teleológico para el mejoramiento de la humanidad. La presente investigación simplemente pretende presentar un ejemplo del popular ámbito deportivo que muestra lo poco que en realidad sabemos de algunas de las cosas mas cercanas a nosotros, como nuestros propios cuerpos o la técnica requerida para correr en línea recta, y como un solo caso es suficiente para tener que replantear décadas de certezas científicas. Este acercamiento interdisciplinario a el caso de Usain Bolt solo intenta mostrar que tan vigente aun esta nuestra ignorancia, así como también nuestras pretenciosas

\footnotetext{
${ }^{1}$ Universidad del Salvador (USAL). Buenos Aries, Argentina.
} 
suposiciones en relación al conocimiento humano. Este humilde modo de acercarse al mismo es absolutamente necesario si realmente queremos colaborar con la educación de nuestra sociedad.

Palabras clave: Deporte. Cambio. Conocimiento.

Resumo: Ao longo da história, vários eventos nos ensinaram que crenças que acreditávamos serem certezas estavam realmente erradas, devido à falta de informações. De qualquer forma, em muitas ocasiões, tendemos a cair no mesmo ciclo, acreditando que desta vez estamos certos e que nosso novo conhecimento faz parte de um movimento teleológico para a melhoria da humanidade. Esta pesquisa visa simplesmente apresentar um exemplo do campo esportivo popular que mostra quão pouco sabemos realmente sobre algumas das coisas mais próximas de nós, como nosso próprio corpo ou a técnica necessária para executar em linha reta e, como único caso, é suficiente para ter que repensar décadas de certezas científicas. Essa abordagem interdisciplinar do caso de Usain Bolt apenas tenta mostrar como ainda está em vigor a nossa ignorância, bem como nossas suposições pretensiosas sobre o conhecimento humano. Este modo humilde de abordá-lo é absolutamente necessário se realmente queremos colaborar com a educação da nossa sociedade.

Palavras-chave: Desporto. Mudança. Conhecimento.

\section{LIFE ALWAYS FINDS A WAY}

Ever since there has been life in our planet it had strived for survival and expansion, overcoming hurdles and pushing through limits. It appears to be nature's way, the way it is constructed: Apparently, life always finds a way. It is true that many lose their own existence in the process, but life as a whole keeps on going, and in many cases, expanding. As Nicholas Nassim Taleb has stated, nature is the personification of antifragility (TALEB, 2013, p. 84).

What does antifragile mean? Antifragile is the exact opposite of fragile when viewed from the perspective of change. Something fragile is an entity that suffers whenever change comes along. And against popular belief, the contrary of that is not an entity that is resilient, something that is not affected by change. The opposite of fragile is something that improves whenever change is presented, something that benefits, that excels in a dynamic environment, perfecting its ways with every opportunity it encounters (TALEB, 2013, p. 57). Antifragile things embrace change and are able to change themselves when their environment demands it. Living organisms, with their plasticity and capacity to adapt to changing environment are antifragile, but even more so is the system that contains them, replacing them whenever it is needed to protect the grander scheme of things. Once again, nature is antifragile. 


\section{HUMANS, THE SPECIAL OPUS?}

If we share this idea about nature, we could easily argue that nature's most impressive single masterpiece has to be humanity. Ever since the Homo sapiens entered the scene, it has adapted and overperformed any competition that it has encountered, including all its close relatives from the Homo genus. Because the general understanding today is not that we evolved from the Homo neanderthalensis or the Homo erectus, but that we coexisted with them and eventually out survived them ${ }^{2}$ (HARARI, 2017, p.19).

How did we do this? Some believe that the biological adaptation that has come to be known as the cognitive revolution needs to be credited with our success: This is the ability to use fictional language in order to unite larger groups of individuals under one single banner, such as a belief, religion or a nation (HARARI, 2017: 38). With this tool we were able to outnumber stronger species like the Homo neanderthalensis, who could only gather in groups small enough to be unified by direct social interactions (DUNBAR, 1998, p.75).

Trying to guess exactly what happened 70.000 years ago can never be an exact science, so for the moment we will leave that discussion at that. What is important is to stress the level of plasticity that the Homo sapiens has possessed since its appearance in the world stage, and to point out how it has constantly surpassed its limitations in order to continuously exceed its capacities, since that is what this research intends to emphasize.

But could we actually believe that we are special? In this work we will refer to a clear example of our capacity to improve, at least when it comes to a simple and impartial measurement. Do we imply by that that we are in fact distinct or superior to the rest of nature's creations? That is not the objective of this work. In fact we will try to show how we have become clearly overconfident, and therefore capable of bigger mistakes, making us look ordinary all over again. We suffer from the survivor's bias, and that might someday be the reason of our own demise. But for now, let us rejoice in the positive, we will get back to the criticism later.

\footnotetext{
${ }^{2}$ Some theories actually claim that we were responsible, for their demise, but dilucidated that with the research up to date is neither prudent or pertinent in this research.
} 


\section{SPORTS}

Some authors will insist in the competitive nature of humans. They will say that it is an essential attribute of them (HOBBES, 2004, p.124), or that it is a logical leftover from our more primitive evolutionary past, where competition determined survival (DAWKINS, 1989). This debate is far from being settled, and the other side of the quarrel has significant arguments to support their claim as well. But being essential or not to our nature, there is no doubt that agonal entertainment is popular across societies, and within this type of entertainment, sports are undoubtedly the most dominant one, in any of its multiple forms.

The relevance of sports in our modern society cannot be exaggerated. This kind of entertainment can hardly be matched by any other type when it comes to live spectators, the amount of resources used in their creation and conservation, or the revenues they generate. Single sporting events will be viewed by the millions, some athletes could be easily considered the most famous persons in the world, and the power wielded by them and some sports organizations is big enough to go toe to toe with many politicians and nations. Their presence in the so-called globalized world, favored by the speed in which information travels through the internet and social media appears to be absolute, and if so, it is in great measure because of our demand for them.

But besides from its importance in the world of entertainment, the significance of sports can be attributed to its capacity to mirror some of the most human characteristics within a specific context. It could be argued that as a raw manifestation of human culture, there are few institutions that would match it, since in a single contest you could witness some of the best and the worst attributes of humanity: Sacrifice, passion, commitment, honor, and of course treachery, pettiness, violence and blunt humiliation. Sometimes, watching sports feels like watching the most real soap opera ever produced, and in many other occasions the reality of sports even supersedes the wildest stories our imagination can generate. It is humanity at its crudest, raw and ready for the taking, and it seems we can never get enough of it.

That being said, sports can be really complex in their structure. This happens because they come out of our own creativity and the possibilities the human body presents, and both have changed and evolved through history. In many occasions a sport has branched out and given birth to new disciplines, in many cases more popular than its previous version. Weather it is because of 
its specifications, its rules, the number of participants, the instruments used in it, the way in which the winner is determined, or even external factors to the sport itself, they are all different, filled with variables that makes each and everyone a unique source of entertainment. The menu of sports is substantial now a days, and only a fool from afar would argue that any of them is not a exceptional specimen worthy of our attention.

But when it comes to sports in its cleanest form, it is hard to make a better case than the one the hundred-meter dash presents, and it is around that specific discipline that our research will revolve, particularly around one individual, and one single event.

\section{THE HUNDRED-METER DASH}

It is difficult to find a simpler and more representative form of sports than the good-old hundred-meter dash. Its purity is undeniable, and it is fair to say that its basic structure has not changed along its official existence. Now, it is also necessary to say "it's official existence" because in some elemental way, this competition has always been around: We probably all competed in some sort of straight forward running race at some point of our life, and so has humanity for as long as we have any records of it (and the fact that we might not have a record from before does not mean that humans were not running against each other at those times too, weather it was for fun or for their survival).

Not only its instructions are as simple as "run from point A to point B in the least amount of time possible using only the athlete's own body", but the objectivity of it's implications are almost undisputable: whoever holds the reigning world record is the fastest man in the history of humanity $^{3}$. It is as close as it can get to objective progress in any human activity, as symbolic and unbiassed as you will ever find. Still, we shouldn't be fooled by its apparent simplicity, since countless variables make running in a straight line incredibly more complex than what an outsider would believe.

Although the discipline of the hundred-meter dash has not changed in its fundamental structure, other than the way time is measured (improving its methods so we can measure

\footnotetext{
${ }^{3}$ It could be argued that potentially there could be faster human being in the planet that have not trained in order to fulfill their full potential, but in act, it is as close as an absolute affirmation as we can get.
} 
differences unperceivable to the human eye), the surface on top of which the competition takes place and the shoes used on it (both of these have transformed in order to better translate the energy created by the athlete's strides on them), most of the factors that end up defining the winner in a race have evolved dramatically.

Why is this so? Probably because although the race itself remains intact, our knowledge in relation to humans, their body and their capacities has changed dramatically in the last hundred years. The athlete still has to run from the first to the hundredth meter as fast as he can, but the way to achieve that feat has been affected by what we have learned and discovered through time with the help of science. And by altering our holistic understanding of the individual that will run that distance, significant changes in the way the enterprise is pursued are inevitable. If we take the beginning of modern Olympics in 1896 as a comparison point, we could say that a lot has transformed around this iconic discipline.

\section{HOW HAS IT CHANGED?}

So, the race remains almost unchanged, but everything that surrounds it does not. How is this possible? There are several points we need to address to answer this question.

Have humans as a specie changed over the last hundred years? From a genetic and scientific point of view, the answer to that inquiry is a resounding no, humans have not changed physiologically or genetically in the last hundred years for it to be of any significance in relation to the competition. But if the human specie has not changed, how can we say that our understanding of the athlete that runs the hundred-meter dash has changed?

An initial part of the answer involves a concept known as muscular plasticity: "This concept was coined to refer to the versatility of the human muscles. Their capacity to adapt to stimuli presented exceeds sciences understanding of the process, and that is why even today we still cannot understand some of the changes we witness in individual cases. Changes that begin at a cellular level, but that extend to the systemic level, give our muscles the possibility to outperform themselves and achieve feats that would initially seem out of the realm of our possibilities" (MIROLI, GONZALEZ LEONI, \& RODRIGUEZ CHIARINI, 2013, p. 276). Our cells possess the capacity to change in size and longitude if the right physical training is provided to them. They can also work in a more 
efficient way through a process known as grouping and several other neuromotor mechanisms that our body can perform through movement specification. Once we recognize that our body can overcome many of its limitations, the perspective of how sports should be addressed changes. Basically, genetics and the environment may be what have determined how fast I can run up to this moment, but specific training is what will determine how fast I will run in the future, if I am willing to put in the work.

The next step is understanding how the body works, how it responds to stimuli, which means understanding which are the adequate stimuli for a person who desires to run the hundred-meter dash in less than ten seconds ${ }^{4}$. This has forced athletes and trainers to change the way they approach sprinting in general in more than one occasion, trying out new possibilities and using new methods until the desired results are achieved, and in many occasions adapting the existing theories to the specific needs of an athlete.

In true, though sprinters practice countless times the technique of the sprint by actually running the hundred meters, their training is far from being simply reduce to that. Today, the periodized training with weights is essential to sprinters (BOMPA, 2000, p.109), particularly lower body exercises of strength and power like the snatch or clean and jerk, Olympic disciplines on their own, whose athletes' physiognomy look nothing like those in running disciplines. Sprinters still run, but that is far from being the only activity they must perform at the elite level.

But another big change has to do with what we have learned in other fields, such as physics. Our knowledge has shifted regarding which are the main factors that end up generating speed in an athlete. The meticulous analysis to which sports have been subjected to in the last three decades has made us understand a little better the mechanics of that which we have been doing for a long time. And let us be clear, it is not that we did not know how to run before, we just did not do it in the most efficient way for modern day hundred-meter dash athletes. We no longer think that the speed with which we move our legs is the only thing that determines how fast we run, but instead we understand that the force imprinted in each step might de as important or even more when trying to achieve the highest final velocity possible.

\footnotetext{
${ }^{4}$ Which ironically will not necessarily be the same exercises that an average person will have to perform in order to just run faster. The specificity of the training can really be beyond our expectations once we dive into a particular discipline.
} 
Yet another important factor must be considered when it comes to the changes surrounding this elemental competition, and that is the democratization of sports. In the last half century sports have become more available to the general public, and this is particularly true in a discipline as popularly practiced as running. This has given scouts and trainers a wider spectrum from where they can choose the individuals that will be submitted to the most intense training in order to become elite athletes (hopefully, with their consent). For this selection, many qualities are analyzed that may include both the physical and the psychological, but here we will only present to examples of characteristics weighed by trainers, just to make our point.

The first one refers to muscle fiber types. A general conception is that for sprinters, the best type of muscle fibers is type II, or fast twitch muscle fibers: This type should be able to perform a quicker contraction than the type I, allowing a better acceleration of every part of the leg. They use anaerobic metabolism to create their fuel, allowing them to generate fast bursts of strength in comparison to type I, but fatiguing quicker than them. Type I on the other hand, using aerobic metabolism, oxygen based, have better resistance, and can maintain their performance for longer periods of time ${ }^{5}$. Current research shows that everybody possesses both types of fibers in their anatomy, but in different percentages. According to some scientists, the conversion from one type to the other is not possible, so the percentages of each type of fiber are determined genetically (INSUA, 2003). Following that idea, individuals with a higher percentage of type II fibers should be more adequate for sprint training. Though the validity of this perspective has been questioned before, it is a factor used to select candidates.

The second example is related to the height of the candidates. It was believed that sprinters should not be too tall, since shorter legs are better prepared for short distances: By having a lower point of inertia, they would have a more efficient movement of the leg (DINTIMAN, TELLEZ, \& WARD, 1997, p.87). Convinced that muscle power was essential for sprinters, the advantages of a not so tall athlete, a compact one, was clear in comparison to a tall one. Niels Uth said in 2005 that "All elite sprinters are in between 1,68 and 1,91 [cm] (...). The fact that the data regarding the height of sprinters is distributed so evenly shows that being too short or too tall is a disadvantage for

\footnotetext{
${ }^{5}$ The classification could include a third type and a more comprehensive explanation, but given the purposes of the research it would be futile to explain everything in detail. A general idea of differences between individuals at the moment of selecting candidates is all that we want to show.
} 
sprinters" (UTH, 2005, p. 612). But, as we will see shortly, three years after that everything would change.

\section{THE HUNDRED-METER DASH IN MODERN TIMES}

It could be easily argued that this contest is the crown jewel of the Olympic games. It is the most important race within track and field (together with the marathon many will argue ${ }^{6}$ ), and its safe to say that track and field is the most emblematic part of the games. And as we have said before, the crowning of the fastest man alive is a very enticing spectacle to watch.

For those ten seconds all eyes are set in the track. Athletes have trained for years, even decades to get to this stage, and although they had other important competitions during their season, this meeting, which occurs only every four years is special in the mind of every single participant. Ten seconds might seem too little time for such a high prestige, but not only must we think of the effort needed to get to this desired final race, but we must also understand that those ten seconds, a time so short that the athletes barely have any time to breath, it is constituted by several stages that to the unprepared audience go by unnoticed.

Not being this a research on the technique or phases of the hundred-meter dash, here we will only try to show its complexity at the moment of the actual competition. According to different theories, these ten seconds should be divided into three, five, or even seven stages, and only as an example, here we will present the seven phases theory and what is expected in each one:

1. Reaction: React to the gun as quickly as possible. A false start implicates disqualification, so a head clear of thought is necessary. It will be crucial for the next stage, and for the overall confidence of the athlete during the rest of race.

2. Block clearance: Eject from the starting blocks with the proper mechanics to set up correctly the rest of the race. Leaning forward in an ideal angle, a lowered head, and force starting from the ankles are crucial for this stage

\footnotetext{
${ }^{6}$ One downside to the other iconic discipline is that few people will watch over two hours of monotonous running unless they are fans of the sport. The ten second span is yet another reason for its popularity: Who doesn't have ten seconds to spare and see history in the making?
} 
3. Drive phase: While leaving the blocks it is important to stay low, at a forty-five degree angle, with good triple extension in the ankles, knees and hips. It lasts the first ten meters, and the focus should be on applying as much force as possible to the ground.

4. Acceleration phase: The head should slowly turn up, from the ground towards the finish line, and it is important to push the hips forward while your feet push back against the track. During this phase it is important to get tall and raise your knees.

5. Top speed: The maximum velocity phase, which athletes might reach usually between the forty- and fifty-meter mark. Body should be upright, with no backward or forward lean, and it should last between 2 and 4 seconds.

6. Speed maintenance: at this point it doesn't make sense to try to accelerate, the focus should be to maintain the speed achieved, loosing as little as possible through the last part of the race. This phase might start at the sixty- or seventy-meter mark, and its important to move legs as quickly and lightly as possible.

7. Finish: A final leaning forward with chest out and arms back is ideal for gaining time. It is necessary to think of the finish line as something you run "through" instead of "at" so that you don't decelerate before you are meant to. It must be timed perfectly so the momentum of the forward leaning fits perfectly. It usually happens in the last two meters of the race.

As we can see, implying that this competition is simply running is an big understatement, and we must understand that each phase will not only be practiced by itself, but specific strength and skill exercises will be needed for all of them. As it usually happens in reality, a case of unnoticed complexity in the "simplest" of motions.

\section{AUGUST $16^{\mathrm{TH}}, 2008$, BEIJING}

Now that we have a vague notion of the dimensions of the hundred-meter dash, we cam focus on the day itself. It was a Saturday afternoon of the 2008 Olympic games, and from inside the stadium known as the Birds Nest, the world was about to witness one of the most iconic and astonishing spectacles that sports have ever produced. The Jamaican phenom known as Usain St. Leo Bolt was about to make history in more than one way, and although some experts and fans 
expected something special, no one could know what was about to happen, and in some way, all that will follow. Describing it through words is impossible, almost disrespectful, but we are going to attempt it (we apologize for that). It only takes ten seconds, so we will also try to make it short, but we will include in this narrative all the details we have learned from his numerous interviews about that day, specially what Usain Bolt tells us himself in his documentary "I Am Bolt"(TURNER \& TURNER, 2016).

It is the time everyone is expecting, the hundred-meter dash final at the Olympic games. Bolt is standing at the starting line with his seven competitors. He has a smile in his face, since as he says, "I was hyper, I was really hyper". The previous night he and his roommate Maurice Smith couldn't rest, while his coach Glenn Mills urged him to go to sleep, but as he says, he was really excited about what was happening the day after.

Hyper he remained at the line, but he settled down into his starting position, focused on the task ahead, without lifting his eyes, in the silence that the Bird's Nest had provided.

The gun sounds, the eight athletes begin their meticulous race, and the roar from the audience follows, as if the gladiators had been unleashed into the coliseum. That is the actual order of events: the athletes gain almost a second to the reaction of the crowd. Not only they have been training for years to execute that reactive motion to perfection, but they also need to release all that energy concealed under their calm appearance.

Bolt's start is a good one, almost in pace with everybody else. He says that in his mind he was thinking "I need to get these fifty right", and he was doing a very decent job. He says that at 30 meters he looked at the others, and he was slightly behind, something to expect due to his "slow" start (sounds ridiculous to call it that, but in comparison to the other's starts, it could be an accurate description) due to his height.

Then at 50 meters he felt he was in line with everyone. He was expecting his countryman, Asafa Powell to be ahead of everyone, but in his own words, "I looked across. He wasn't there... So, you know what? Continue running...". He keeps on going, at this moment extending his long legs to their fullest potential, he reaches the sixty-meter mark and checks again, but no competitor is in sight. The gap generated up to that moment was already such that in order to see others, he had to turn his head, and he was not going to risk losing his form with so much race still ahead. 
He ran to the seventy-meter mark, it looks like he is flying at this point, and still nothing, no one around. And when he reached the eighty-meter mark he says, "I was like, 'Where's Asafa?! You know what I mean?'... And then I was, like 'Oh shit, I'm gonna win!'”. And indeed, he was.

In a close lateral frame, you could no longer see Powell or any of his competitors for that matter. The margin was so big, and he had reached such a superior speed that it was impossible for someone to catch up to him. As the announcer screams "Usain Bolt, sprinting ahead, winning by daylight!", Bolt already opened his arms, breaking any kind of composure that his training has imprinted on him for the final meters.

"I started beating my chest", he says, something that some had considered disrespectful, but that all have found at least uncommon, since while doing that he is probably losing precious time. Only when winning by a ridiculous margin could a sprinter do such a thing, and how much margin could be made in one hundred meters against the best in the world? If you are Usain Bolt on that Saturday in Beijing, the answer is plenty indeed, and he knew it.

As he explained later, "People are saying why did I celebrate? Well, it just happened. It just came out of me because that's what I felt. You're coming up to the line and you go, 'Oh, This is it. This is it. This is what I've been working on.' I can't believe I finally done it... It's so much work to get to that one moment, to win that one moment." Then, what is the explanation for his celebration? A reaction of pure joy, supported by the time to spare that his performance had granted him.

This was indeed a unique, singular moment, generated by a unique, singular man whose accomplishments will only continue to pile on in the two-hundred-meter dash and the four by onehundred-meter relay, that same year ${ }^{7}$, in London 2012, and in Rio 2016. This was just the beginning, and what a beginning it was. Gold medal, and a new world record, 9.69.

\section{A PARADIGM CHANGING EVENT}

\footnotetext{
${ }^{7}$ Since 2018 he is no longer attributed the $4 \times 100$ m relay in Beijing due to a positive doping case on his teammate, Nesta Carter. Yet, just to maintain his undefeated state, it is fair to say that they won the actual race for such a margin that any other Jamaican sprinter could have run in Carter's place and they would have still won. That particular effort will not be deserving of a medal, but at least it deserves a footnote.
} 
As of today, the fastest man to ever live is still 1,96 meters tall, so its is safe to say that Uth and many other's theories about medium height sprinters can be safely discarded. But why is he the fastest man to ever live if his body type was supposed to be the wrong one? Without a doubt, by a long list of merits that the Jamaican athlete possess that include, but do not limit to strength, commitment to unrelentless effort, the ability to perform under tremendous pressure, and a singular passion for doing what he loves. But it is also clear that one of those unique and necessary characteristics to generate this "once in a generation" kind of athlete is the fact that he finishes the hundred-meter dash in 41 strides while in average his contenders need 44.

His height, which include his long legs, have been a valuable asset for him. That which at some point would have seemed a detriment to his speed aspirations ended up being a fundamental ingredient in his recipe for his reigning world record of 9,58 seconds. And at this point it does not seem unthinkable: his steps at full speed are twenty centimeters longer than those of his competitors (MERO \& KRZYSZTOF, 2013, p.158). There is no doubt that he needs to accompany his long extremities with an exemplar strenght and power, fruit of his very specific training and phisiology, but in many ways, what differentiates him from many others is not his training, which many could imitate if they thought it was the key to his success. What uniquely separates Bolt from the rest of the sprinters are his antropometric qualities. Even his increased weight starts to be an advantage in the final part of the race, when the maximum velocity has been reached and inertia collaborates with maintaining the velocity already accomplished, avoiding deceleration at the moment when the fast consuming energy (ATP) starts to run out (FORTEZA SOLER, COMELLAS HUMET, \& LOPEZ DE VIÑASPE GARCIA, 2013, p.117).

Does this mean that in the future all sprinters will be as tall as Usain Bolt? Although many might be compelled to answer yes to that question, the wise answer would be, not necessarily: There could be a new change of paradigm, like a revolutionary training or food or mutation with the capacity to generate type II cells, returning to the theory that medium length legs can better seize the power they generate.

The appearance of Bolt should only teach us a long overdue lesson: Reality tends to shows us how our irrefutable theories are often mistaken. In most cases, the final word has not yet been said, and we should be humbled by that, not defeated. Still, we tend to miss that fundamental lesson. 


\section{THE IDEA OF PROGRESS}

Progress is, to say the least, a controversial concept, bordering dangerous. The teleological conception that humanity is advancing through a path which at the end contains our best version is very misleading indeed, and one that through history has been used by many to convince others of their own objectives.

We do not know what the future will bring, that is probably one of the only truths we can count on. Following that idea, we don not know the ultimate destination where our decisions (as an individual), discoveries, inventions or policies (as a society) will take us. Trying to predict it is closer to clairvoyance than science. Still, we choose to trust predictions made by experts, constantly.

Do we know the consequences that social media will eventually have? Many believe that they are a danger to society and would have this novel form of expression banned from our societies. But didn't similar individuals in a different context curse Elvis in his first appearances because he dangerously moved his hips? And years after that, do we enjoy his music and the joy it brings, or do we still believe that The King was the devil?

It is hard to argue what is good and bad, because as Thomas Hobbes (HOBBES, 2004, p.75) said over four hundred years ago, good or bad are based on the subject's feelings of desire or aversion towards something, not on objective qualities of things. Circumstance will repeatedly change our perspective regarding most objects and issues, so a wise person's judgment needs to be cautious, and never definitive.

But could we consider Usain Bolt's performance as progress? In such an objective field, and in the search for self-improvement in mind, we could agree that his accomplishments indeed represent progress in the athletic field. But that is as far as it should go.

Since we don't know the path our decisions will take us, we cannot know if a decision or a policy is a good one or a bad one with absolute certainty. In this complex world in which we live in, all we can expect are educated guesses, based on contingent knowledge. Believing we have discovered the key to progress is an illusion: Constant change is the only reality, and we need to keep adapting to it. Mother nature has already taught us that not all adaptations are fruitful ones, 
but we won't probably know their outcomes for a long time. Maybe we should try to be a little cautious on our judgements until then, and not so trustworthy of our knowledge, or the illusion of it.

\section{KNOWLEDGE AS THERAPY}

It is safe to say that we, humanity as a collective entity, know a lot of things. That is a statement we can all agree with. But we should also agree that there is a lot more to be known about reality, and that the things we think we know, aren't really certainties. As far as we are concerned, the amount of knowledge that could be obtained regarding our universe is infinite, and we should be aware that even with our current advancements in most sciences, we are just scratching the surface. But that is usually not the case, and it never has been.

Although a scientist in a specific field might be aware of how much is unknown within it, a large portion of the general public usually isn't. This happens for various reasons, including the idea previously stated that we do have a lot of knowledge, but probably the most significant one is the fact that we simply need to know. As Nassim Nicholas Taleb says, we tend to use knowledge as therapy: We need to think that we know, it makes life easier (TALEB, 2009, p.132). We prefer not to be aware of the level of ignorance we actually have, and it has always been like this.

A clear example is the need we have always suffered to explain why things happen. It doesn't matter if the answer is that we did something in our past life, that god has a plan, or that it rains because the local Chaman has performed the ritual correctly. We just need an answer, because the alternative is accepting that we don't know, and if we don't know why things happen, we probably won't be able to predict what is going to happen next. And that means anything could happen, which is a terrifying thought.

We would rather think that we know, even if we know erroneously, than accepting that we don't. Some say that, physiologically, we are actually wired to act in that way, being uncontrollable situations a natural generator of stress for our nervous system, that can only be inhibited by the prefrontal cortex perception of control (MAIER \& SELIGMAN, 2016, p.353). But even if that is the case, and we need to apply those solutions to our everyday life, we need to draw a line when it 
comes to knowledge obtained through science and research, since only problems might come from that sort of overconfidence.

\section{CONCLUSION}

Bolt's remarkable performance in Beijing 2008 should rightfully keep us in aw of the magnificence of the human spirit. As evidence of our ability to dream and accomplish those dreams, of pushing ourselves past great limits, beyond our wildest imagination. The human strength and the human mind should never be underestimated.

But at the same time, Bolt's appearance shows us the need to be humble: that our theories might be wrong, that we don't have the answers to all the questions, and that we should be constantly learning lessons knowing that in the future, those lessons might turn out to be mistaken. It only takes one black swan to disregard the notion that all swans are white, and it only takes one Bolt to discard years of expert opinions.

And if we still have so much to learn about running in a straight line, what is left for the rest of the disciplines and sciences? What is left for the rest of human knowledge? Fortunately, a lot. All that is needed is the awareness of this reality, and a "Boltian" willingness to keep pursuing the everevasive truth (or world record) about the universe we live in. This is the way we can advance in sports and in life, a thousand of a second at a time. We may think it is not much, and we'll probably not get an Olympic medal at the end, but we must never forget that that is also pushing our limits and chasing our dreams. Bear in mind, not all of us can be the Jamaican phenom.

\section{REFERÊNCIAS}

BOMPA, T. O. Periodizacion del entrenamiento deportivo. Barcelona: Editorial Paidotribo. 2000.

BURFOOT, A. Ultimate 100-Meter Time: 9.27 Seconds? Runner's world. 2014.

CHARLES, J. D., \& BEJAN, A. The journal of experimental biology. 2009, Mayo 5. Retrieved from http://jeb.biologists.org/content/212/15/2419.short

DAWKINS, R. The Selfish Gene. New York: Oxford University Press. 1989. 
DINTIMAN, G., TELLEZ, T., \& WARD, R. Sports Speed 2nd Edition. USA: Leisure Press. 1997.

DUNBAR, R. Grooming, Gossip, and the Evolution of Language. Cambridge: Harvard Univarsity Press. 1998.

FORTEZA SOLER, K., COMELLAS HUMET, J., \& LOPEZ DE VIÑASPE GARCIA, P. (2013). El entrenador personal. Barbera del Valles: Editorial Hispano Europea. 2013.

HARARI, Y. N. De animales a dioses. Buenos Aires: Debate. 2017.

HOBBES, T. Leviatan. Buenos Aires: Losada. 2004.

INSUA, M. F. Plasticidad Muscular. Retrieved from EF Deportes Revista Digital:

http://www.efdeportes.com/ 2003.

KOLHAAS, J., BARTOLOMUCCI, A., BUWALDA, B., DE BOER, S., FLUGGE, G., KORTE, S., FUCHS, E. Stress revisited: Acritical evaluation of the stress concept. Neuroscience and Behavioral Reviews, 35, 1291-1301. 2011.

MAIER, S., \& SELIGMAN, M. Learned Helplessness at Fifty: Insights From Neuroscience.

Sychological Review, 123(4), 349-367. 2016.

MERO, A., \& KRZYSZTOF, M. National center for biotechnology information. Retrieved from Journal of human kinetics: http://www.ncbi.nlm.nih.gov/pmc/articles/PMC3661886/Marzo 28. 2013.

MIROLI, A. G., GONZALEZ LEONI, M., \& RODRIGUEZ CHIARINI, S. Mecanicismo y plasticidad. In Anuario de investigacion de la Universidad del Salvador (p. 276). Buenos Aires: Universidad del Salvador. Retrieved from Mecanicismo y plasticidad mnuscular: http://p3.usal.edu.ar/index.php/anuarioinvestigacion/article/view/2423 2013.

TALEB, N. N. (2009). El Cisne Negro. Buenos Aires: Paidos. 2009.

TALEB, N. N. Antifragil: las coas que se benefician del desorden. Buenos Aires: Paidos. 2013.

TURNER, B., \& TURNER, G. (Directors) I am Bolt [Motion Picture]. Retrieved March 8, 2018 Uth, N. (2005, Diciembre 1). National center for biotechnology information. Retrieved from Journal of sports science \& medicine: http://www.ncbi.nlm.nih.gov/pmc/articles/PMC3899678/ 2016.

\section{ABOUT THE AUTHOR}

\section{Mariano Gonzalez Leoni}

Master of Arts in the Humanities (University of Chicago - USA). Doctorando en Filosofía pela Universidad de Lanús (Argentina). E-mail: mgonzalezleoni@gmail.com

Orcid: https://orcid.org/0000-0002-2798-1983 
Received on: 01-18-2020

Approved on: 02-20-2020

Published on: 03-01-2020 